\title{
Den kompliserte maten
}

\author{
Spiser pasienten ernæringsriktig, \\ holder han seg frisk lenger, blir \\ raskere restituert etter å ha vært \\ syk og trenger dermed færre kost- \\ bare medikamenter. Det høres \\ fornuftig og samfunnsøkonomisk \\ ut, men blir selvsagt vanskelig \\ i praksis. Mat og medisin faller \\ som vi vet inn under to vidt for- \\ skjellige budsjetter.
}

| England går $10 \%$ av helsebudsjettet til behandling av underernærte. I Norge kan man ifølge Hanne Juul spare 800 millioner i året på forebygging og behandling. Legene og kokkene burde i grunnen samarbeide mer. Vi vet begge hva som skal til, og de hvite uniformene inngir en viss respekt som kanskje ville gjøre at pasientene hørte etter.

Det som skjer på sykehuset har man en viss kontroll på. Problemet er det som skjer før pasienten kommer dit. De fleste eldre bor hjemme. Hjemmeboende eldre med behov for det får tilkjørt mat fra kommunen. Vel og bra, men sitter man ensom og spiser, glimrer appetitten ofte med sitt fravær. Maten kan være delikat tilberedt og inneholde så mange næringsstoffer at det nærmest skvulper over. Men finner ikke maten veien fra tallerkenen og opp til munnen, de siste tretticentimeterne, så har maten ingen verdi. Og når de eldre først blir underernærte, så er hovedregelen at løpet er kjørt.

Mat på institusjoner kritiseres ofte for å være kjedelig. Dette er en kjent og kjær gjenganger i tabloidavisene. Man presenterer en grå og trist pasient samt en matrett som matcher pasienten. En høyrøstet kjendiskokk gir terningkast én. Restaurantmat på sykehjemmet høres forlokkende ut. Man ser for seg en høy kokkehatt komme med en serveringstralle kledd med hvit damask. Vinglass i fineste böhmerkrystall og tallerken av merket Flora Danica, der det åpenbarer seg en saftig filet mignon flambé au cognac, servert med champignons à la crème og sesongens primeurs kokt al dente.

Man har noen hyggelige bilder i hodet. Eget kjøkken på hvert sykehjem, høye kokkehatter lager kjente og kjære tradisjonsretter av kortreiste råvarer, matlukten sprer seg i gangene og fører til trivsel og appetitt. Nå er ikke virkeligheten alltid slik. For å si det småbrutalt: Grønnsakene kan være så al dente de bare vil, men hvis gamle Andersen ikke kan tygge, så klarer han ikke spise dem.

Sykehjemsmaten lages som oftest ikke på stedet. Små kjøkken legges ned. Kanskje kommer maten fra sentralkjøkkenet i nabokommunen, kjøres kaldt til sykehjemmet, for så å varmes opp noen dager senere. Det er dette som kalles kok/kjøl. Som regel er det pleierne som tar seg av oppvarming og servering. Noen vil kanskje tenke at det ikke er den beste personalutnyttelsen, men kokkene forsvant jo sammen med kjøkkenet. Økonomisjefer er overbevist om at det lønner seg å gjøre det på denne måten.

Fort gjort ogsåå glemme at pengene som skal dekke frokost, lunsj, middag, dessert, kvelds og mellommåltider bare tilsvarer det en enkel forrett koster på en middels restaurant. Dessuten, de tekniske kravene til dagens ventilasjonsanlegg er så strenge at knapt nok kjøkkenpersonalet kjenner denne matlukten som alle er så opptatt av.

Det er noe usunt med et system der den som lager maten aldri møter de som spiser den. Fremmedgjøring satt i system. Man kan lage fine og nøyaktige regnestykker med grafer og kolonner - og likevel få galt svar. Fjerner man kjøkkenet, fjerner man den matfaglige kompetansen. Det betyr kanskje ikke all verden for regnskapets del, men det kan bety mye for pasienten som ser på måltidene som dagens høydepunkt, ikke bare som nødvendig fôring. Det kan bety riktig mye for pasienten som er så langt nede for telling at eneste måten å få ham til å spise på, er å tilby ønskekost. Det er generelt vanskelig å imøtekomme mat$ø n s k e r$ uten noe kjøkken. Kanskje skulle man hatt en kokk på stedet likevel?

I Østfold tar man filosofien et par skritt videre. På Kalnes bygges det nytt sykehus av den riktig store sorten. Sykehuset skal ikke ha produksjonskjøkken. Maten skal kjøpes fra et av sykehusene i nabofylkene, fraktes et relativt godt stykke på veien og så varmes opp på Kalnes. Det kan man jo mene mye om. Det har undertegnede for så vidt også gjort, og det er all grunn til å tro at julekortene fra Østfold uteblir i overskuelig fremtid.

Karolinska Universitetssjukhuset i Stockholm åpnet for ti år siden. De valgte den samme løsningen der, uten produksjonskjøkken. Maten skulle kjøpes et annet sted. Karolinska har gjort seg noen interessante erfaringer, gått noen runder med seg selv og skal nå likevel bygge produksjonskjøkken. Det skal stå ferdig i 2018. Det samme skjer i Uppsala.

Nevner det bare.

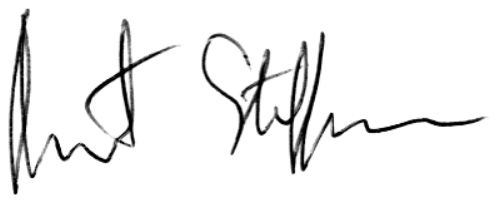

